\title{
Sistem Informasi Pengelolaan Data Alumni Pada UPT SMK Negeri 1 Musi Banyuasin
}

\author{
Risviliani Afrilia, Zaid Romegar Mair \& Juansyah \\ Teknik Informatika, Politeknik Sekayu \\ Email : risviliania@gmail.com
}

\begin{abstract}
This research was conducted to create an Alumni data management information system at UPT SMK Negeri 1 Musi Banyuasin. This system designed specifically for managing alumni data is expected to make it easier for staff to manage alumni data and make it easier for alumni to fill in alumni data without having to come to school. The focus in this research is to create a system using programming languages that have been widely used, namely PHP and MySQL and to report the data using FPDF. Data Collection Methods in this study are about the Alumni data management information system at UPT SMK Negeri 1 Musi Banyuasin. This study shows the results that to present information on the Alumni of UPT SMK Negeri 1 Musi Banyuasin which includes the presentation of alumni data. As well as other information that is deemed necessary to be presented when needed, such as facilitating the search for old or new alumni. The development of this web-based information system will make it easier to handle changes in data, be it adding, subtracting or searching for data.
\end{abstract}

Keywords: information system of data alumni, alumni

\section{Pendahuluan}

Pendataan alumni biasa dilakukan dengan mengumpulkan atau mengisi biodata disekolah. Hal ini kurang efisien karena tidak semua alumni bisa datang ke sekolah untuk mengisi data, Tidak sedikit para alumni yang setelah lulus melanjutkan pendidikan atau pergi ke luar kota untuk bekerja dan mereka biasanyaenggan untuk kembali sekolahnya hanya untuk mengisi data alumni.

Maka dari itu dibutuhkan suatu wadah atau media yang menyediakan layanan untuk kebutuhan pengumpulan data para alumni yang dapat mendukung pemberian informasi dan juga mudah dalam penggunannya serta ringan, cepat, dan mudah. Data-data tersebut meliputi nama, angkatan, tempat tinggal dan beberapa tambahan data lainnya. Alumni merupakan bagian dari keberadaan suatu lembaga pendidikan. Keberadaan alumni saat ini sudah menjadi salah satu syarat penelitian akreditasi suatu lembaga pendidikan. Dengan mengetahui keberadaan para alumni maka lembaga pendidikan dapat mengetahui sejauh mana keberhasilan dalam mendidik hingga siap bekerja.

Alumni juga memiliki peranan penting untuk pengembangan institusi pendidikan. Karena alumni bisa berperan sebagai cermin kualitas sebuah institusi pendidikan diranah publik. Dengan adanya informasi tentang alumni yang baik secara tidak langsung dapat meningkatkan citra baik sekolah terhadap masyarakat umum. Sampai saat ini masih banyak sekolah yang belum memanfaatkan penggunaan sistem informasi dalam pendataan alumni, yang diharapkan dapat mempermudah dalam hal pengolahan data alumni Dan mempermudah memperoleh informasi data alumni UPT SMK Negeri 1 Musi Banyuasin, 


\section{Tinjauan Literatur}

\subsection{Sejarah Singkat}

UPT SMK Negeri 1 Musi Banyuasin Banyuasin. merupakan salah satu lembaga pendidikan menengah kejuruan yang ada di Kabupaten Musi Banyuasin Berdasarkan surat keputusan menteri Pendidikan dan Kebudayaan Republik Indonesia No. 0596/0/1985 tanggal 22 November 1985 SMEA (Sekolah Menengah Ekonomi Atas) persiapan pemuda Musi Banyuasin disahkan menjadi SMEA Negeri Sekayu. Secara definitive disahkannya menjadi SMEA Negeri Sekayu berdasarkan SK Mendikbud RI No. 108/C4/KEP/1986. Peresmian pemakaian gedung SMEA Negeri Sekayu oleh bapak Gubernur Sumatera Selatan H. Ramli Hasan Basri pada tanggal 8 Desember 1992. Perubahan SMEA Negeri Sekayu ke SMK Negeri 1 Sekayu berdasarkan SK Mendiknas Nomor: 036/o/1997 tanggal 5 April 1997. Penetapan SMK yang berpotensi untuk dikembangkan menjadi SMK berstandar Nasional/Internasional oleh Direktorat Jenderal Manajemen Pendidikan Dasar dan Menengah Depdiknas Nomor: 3530/C5.3/MN/2005 tanggal 14 Oktober 2005 untuk SMK Negeri 1 Sekayu dengan program unggulan akuntansi. Akreditasi program keahlian akuntansi berdasarkan surat kepala badan akreditasi sekolah provinsi Sumatera Selatan Nomor: MK. 008330.11.00.MK.0009.08 tanggal 12 Desember 2007 dengan memperoleh akreditasi peringkat A.

\subsection{Visi dan Misi}

1) Visi

Dalam Rangka mencapai tujuan UPT SMK Negeri 1 Musi Banyuasin Menetapkan Visi dan Misi dengan target sebagai baerikut:

"Mencetak tenaga kerja yang beriman, kompeten, berjiwawirausaha, dan mencintai lingkungan".

2) Misi

Untuk Mewujudkan Visi UPT SMK Negeri 1 Musi Banyuasin Menetapkan Misi Sekolah Sebagai Berikut :

1) Menumbuhkan penghayatan terhadap ajaran agama yang di anut

2) Melaksanakan kegiatan belajar mengajar yang berkualitas

3) Melatih peserta didik agar menguasai IPTEK

4) Menumbuhkan semangat berwirausaha

5) Membudayakan hidup bersih, sehat dan melestarikan lingkungan hidup.

\subsection{Struktur}

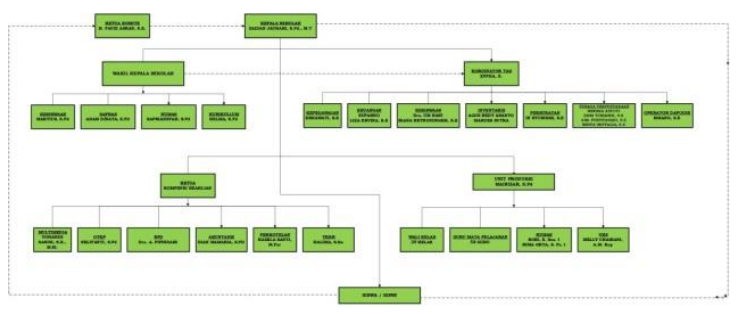

Gambar 2.1 Struktur UPT SMK Negeri 1 Musi Banyuasin 


\subsection{Sistem Informasi}

Dalam bukunya Bambang Hartono (2013:16). Menurut Lippeveld, Sauerborn, dan Bodart (2000), sistem informasi adalah seperangkat komponen yang saling berhubungan, yang bekerja untuk mengumpulkan dan menyimpan data serta mengolahnya menjadi informasi yang digunakan.

Menurut Agus Mulyanto (Mulyanto, 2009:29), "Sistem informasi merupakan suatu komponen yang terdiri dari manusia, teknologi informasi, dan prosedur kerja yang memproses, menyimpan, menganalisis, dan menyebarkan informasi untuk mencapai suatu tujuan".

Menurut Sutarman (2012:13), "Sistem informasi adalah sistem yang dapat didefinisikan dengan mengumpulkan, memperoses, menyimpan, menganalisis, menyebarkan informasi untuk tujuan tertentu. Seperti sistem lainnya, sebuah sistem informasi terdiri atas input (data, instruksi) dan output (laporan, kalkulasi)".

Menurut Sutabri (2012:46), Sistem informasi adalah suatu sistem didalam suatu organisasi yang mempertemukan kebutuhan pengolahan transaksi harian yang mendukung fungsi operasi organisasi yang bersifat manajerial dengan kegiatan strategi dari suatu organisasi untuk dapat menyediakan kepada pihak luar tertentu dengan laporanlaporan yang diperlukan.

Berdasarkan beberapa pendapat yang dikemukakan di atas dapat ditarik kesimpulan bahwa "Sistem informasi adalah sebuah sistem yang terdiri dari pengumpulan, pemasukan, pemrosesan data, penyimpanan, pengolahan, pengendalian dan pelaporan sehingga tercapai sebuah informasi yang mendukung pengambilan keputusan didalam suatu organisasi untuk dapat mencapai sasaran dan tujuannya".

\subsection{Internet}

Menurut Sibero (2011) Internet atau juga yang merupakan kependekan dari Interconnected Network adalah sebuah jaringan komputer yang menghubungkan antar komputer secara global.

Interconnection network atau internet adalah sistem global dari seluruh jaringan komputer yang saling terhubung satu dengan lainnya. Kata internet berasal dari bahasa latin "inter" yang berarti "antara". Internet merupakan jaringan yang terdiri dari milyaran komputer yang ada di seluruh dunia. Internet ini melibatkan berbagai jenis komputer serta topology jaringan yang berbeda.

\subsection{Website}

Menurut Bekti (2015:35) Website merupakan "kumpulan halaman-halaman yang digunakan untuk menampilkan informasi teks, gambar diam atau gerak, animasi, suara, dan atau gabungan dari semuanya, baik yang bersifat statis maupun dinamis yang membentuk satu rangkaian bangunan yang saling terkait, yang masing- masing masing dihubungkan dengan jaringan-jaringan halaman".

Website terdiri dari 3 kategori yaitu Statis, dinamis dan interaktif (Syahid, Bilal 2019, 18 Pengertian Website Menurut Para Ahli,

1) Website Statis

Website statis adalah suatu Website yang memiliki halaman yang tidak hanya 
dapat dilakukan secara manual, yaitu dengan mengedit kode-kode yang menjadi struktur dari Website itu sendiri.

2) Website dinamis

Website dinamis adalah suatu Website yang secara strukturnya diperuntukkan untuk update sesering mungkin. Website ini selain utamanya untuk diakses oleh para pengguna juga telah disediakan halaman backhend yaitu untuk mengedit kode dari Website tersebut.

3) Website interaktif

Website interaktif adalah suatu Website yang diperuntukkan untuk berinteraksi dengan orang lain secara online. Pengguna Website jenis ini biasanya komunitas atau pengguna internet aktif. Pengguna di Website ini dapat berinteraksi dan beradu argumen tentang apa yang sedang mereka pikirkan.

Kesimpulannya Website adalah sebuah informasi yang di tampilkan melalui internet baik Web statis maupun dinamis yang berisi informasi teks, gambar yang diam ataupun bergerak, suara, dan gabungan dari semuanya serta di hubungkan ke halaman informasi yang lain melalui (hyperlink) dan biasanya menggunakan Web Browser untuk membukanya (Antoni, Fikari \& Akbar, 2018; Antoni \& Akbar, 2019; Antoni, Jie \& Abareshi, 2020; Antoni, Herdiansyah, Akbar \& Sumitro, 2021).

\subsection{Unified Modeling Language (UML)}

Menurut Sukamto dan Shalahuddin (2013:133) adalah "standar bahasa yang banyak digunakan di dunia industri untuk mendefinisikan requirement, membuat analisis dan desain, serta menggambarkan arsitektur dalam pemrograman beroriantasi objek". UML (Unified Modeling Language) adalah sebuah bahasa yang telah menjadi standar dalam industri untuk visualisasi, merancang dan mendokumentasikan sistem perangkat lunak. Jadi UML (Unified Modeling Language) merupakan suatu bahasa pemodelan yang menjadi standar dalam industri yang digunakan untuk visualisasi, merancang, dan mendokumentasikan suatu perangkat lunak yang berparadigma orientasi objek.

Secara konsep dasar UML (Unified Modeling Language) mendefinisikan sembilan diagram, akan tetapi dalam hal ini hanya akan dibahas sebanyak empat diagram antara lain use case diagram, activity diagram, class diagram dan component diagram. Berikut beberapa tipe diagram UML(Unified Modeling Language).

\subsection{Protoype}

Prototype adalah salat satu metode pengembangan perangkat lunak yang banyak digunakan . Dengan menggunakan Metode prototyping ini, pengembangan dan pelanggan dapat saling berinteraksi selama proses pembuatan sistem. Sering terjadi seorang pelanggan hanya mendefinisikan secara umum apa yang dibutuhkan, pemrosesan dan data-data apa saja yang dibutuhkan. 


\begin{tabular}{l|l|lr} 
J & $\mathbf{N}$ & $\begin{array}{l}\text { JURNAL } \\
\text { NASIONAL } \\
\text { ILMU } \\
\text { KOMPUTER }\end{array}$ & Jurnal Nasional Ilmu Komputer \\
I & $\mathrm{K}$ & e-ISSN: 2746-1343 \\
\hline
\end{tabular}

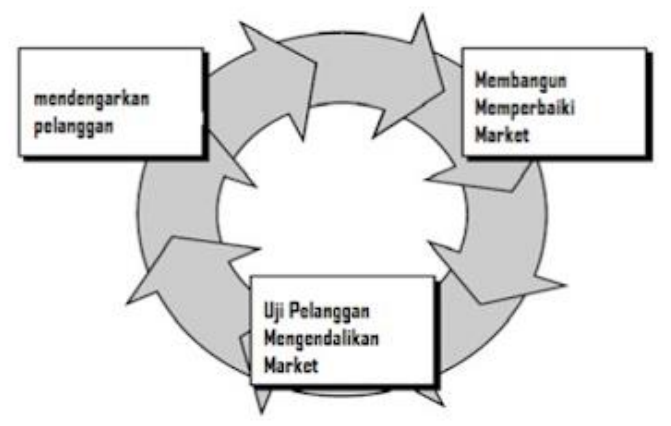

Gambar 2.2 Metode Prototype

1. Pengumpulan Kebutuhan .

Developer dan klien bertemu dan menentukan tujuan umum, kebutuhan yang diketahui dan gambaran bagian - bagian yang akan dibutuhkan berikutnya . Detail kebutuhan mungkin tidak dibicarakan disini, pada awal pengumpulan kebutuhan.

2. Perancangan .

Perancangan dilakukan cepat dan rancangan mewakili aspek software yang diketahui dan rancangan ini menjadi dasar pembuatan prototype.

3. Evaluasi Prototype .

Klien mengevaluasi prototype yang dibuat dan dipergunakan untuk memperjelas kebutuhan software.

\subsection{Teori Pengujian}

Proses tahapan pengujian adalah sebuah proses terhadap aplikasi/program untuk menemukan segala kesalahan dan segala kemungkinan yang akan menimbulkan kesalahan sesuai dengan spesifikasi perangkat lunak yang telah ditentukan sebelum aplikasi tersebut diserahkan kepada pengguna.

Ada beberapa jenis metode untuk melakukan pengujian perangkat lunak, yaitu:

1) White Box Testing

White Box Testing secara umum merupakan jenis testing yang lebih berkonsentrasi kepada source code dari perangkat lunak yang dibuat. Menurut Khan, 2011 dalam jurnal ilmiah teknologi informasi terapan M. Sidi Mustaqbal, dkk Pengujian Aplikasi Menggunakan Black Box Testing Boundary Value Analysis, 2015, mendefinisikan white box testing sebagai pengujuan yang didasarkan pada pengecekan terhadap detail perancangan, menggunakan struktur kontrol dari desain program secara prosedural untukk membagi pengujian ke dalam beberapa kasus pengujian.

Dengan menggunakan white box akan didapatkan kasus uji yang :

a) Menguji semua keputusan logikal

b) Menguji seluruh Loop yang sesuai dengan batasannya

c) Menguji seluruh struktur data internal yang menjamin validitas.

Langkah-langkah White Box: 
a) Mendefinisikan semua alur logika

b) Membangun kasus untuk digunakan dalam pengujian

c) Melakukan pengujian.

2) Black Box Testing

Black box testing adalah pengujian yang dilakukan untuk mengetahui kesalahan fungsionalitas fitur pasa sebuah aplikasi. Black box testing terfokus pada apakah unit program memenuhi kebutuhan (requirement) yang disebutkan dalam spesifikasi. Pada black box testing, cara pengujian hanya dilakukan dengan menjalankan atau mengeksekusi unit atau modul, kemudian diamati apakah hasil dari unit itu sesuai dengan proses yang diinginkan.

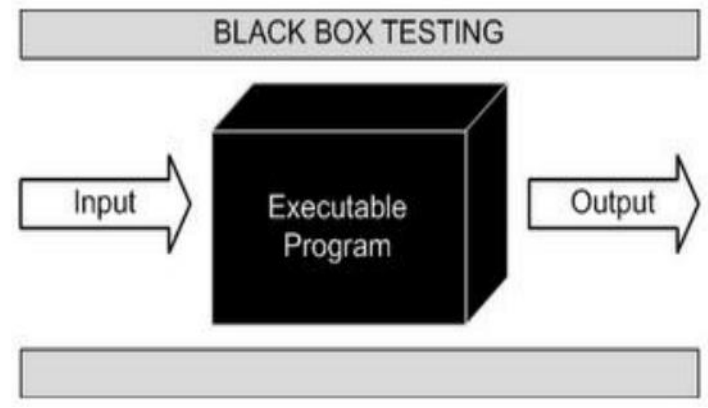

Gambar 2.5 Pengujian Metode Black Box Testing

Teknik yang digunakan dalam Black Box Testing antara lain :

a) Digunakan untuk menguji fungsi-fungsi khusus dari perangkat lunak.

b) Kebenaran perangkat lunak yang diuji hanya dilihat berdasarkan keluaran (Output) yang dihasilkan.

c) Kemampuan program dalam memenuhi kebutuhan pemakai dapat diukur sekaligus dapat diketahui kesalahan-kesalahannya.

\section{Metode Penelitian}

\subsection{Analisis Sistem}

\subsubsection{Analisis Sistem Yang Sedang Berjalan}

Berdasarkan hasil penelitian yang dilakukan pengisian Data Alumni pada UPT SMK N 1 Musi banyuasin masih dilakukan secara manual dan belum terkomputerisasi, yaitu: alumni masih datang ke sekolah untuk mengisi data alumni (Fauzi, Dencik \& Asiati, 2019). Adapun alur kerja yang penulis gambarkan dalam flowchart yang sedang berjalan adalah sebagai berikut: 


\begin{tabular}{l|l|lr} 
J & $\mathbf{N}$ & $\begin{array}{l}\text { JURNAL } \\
\text { NASIONAL } \\
\text { ILMU }\end{array}$ & Jurnal Nasional Ilmu Komputer \\
KOMPUTER & $\mathrm{K}$ & e-ISSN: 2746-1343 \\
KOMPI. 2, No. 2, Mei 2021 \\
\hline
\end{tabular}

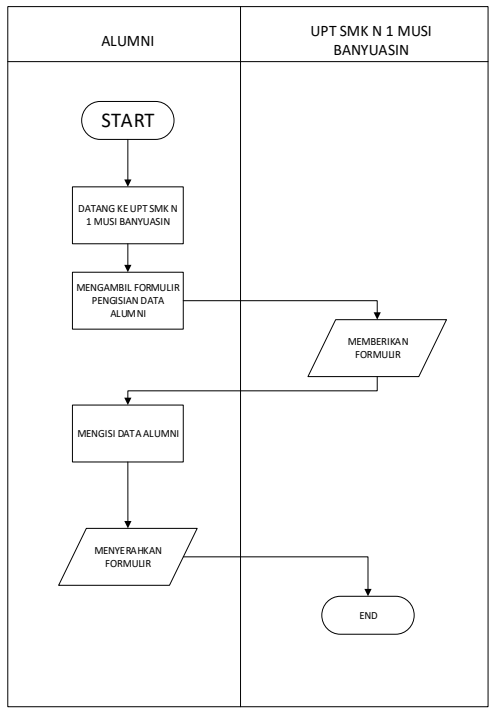

Gambar 3.1 Flowchart Sistem yang sedang Berjalan

Adapun sistem yang sedang berjalan dalam Proses perancangan Sistem yaitu:

1) Alumni mendatangi UPT SMK Negeri 1 Musi Banyuasin .

2) Alumni mengambil formulir pengisian data alumni

3) Pihak sekolah memberikan formulir pengisian data.

4) Alumni mengisi data

\section{2 Analisis Sistem Yang Sedang di Usulkan}

Berdasarkan Sistem yang sedang berjalan penulis mengusulkan Sistem yang baru agar lebih mudah dan Adapun alur kerja yang penulis gambarkan dalam flowchart adalah sebagai berikut :

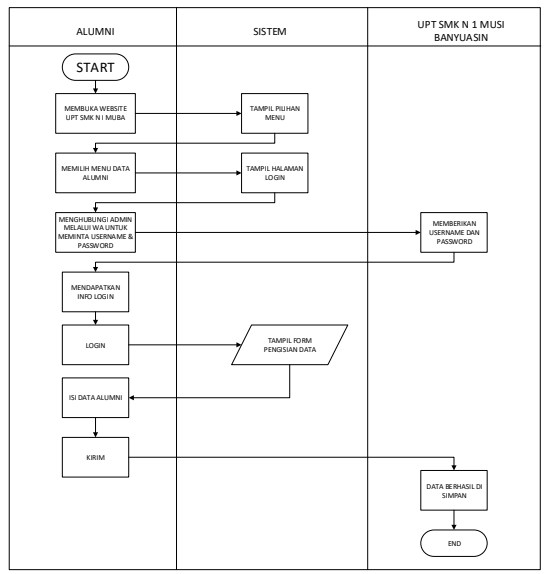

Gambar 3.2 Flowchart Sistem yang diusulkan

Adapun Sistem yang diusulkan dalam Proses perancangan Sistem,yaitu :

1) Alumni mengunjungi Website UPT SMK N 1 Musi Banyuasin.

2) Sistem menampilkan menu

3) Alumni memilih menu data alumni 
4) Sistem menampilkan halaman login

5) Alumni menghubungi admin untuk meminta username \& password

6) Admin memberikan username \& password

7) Alumni mendapatkan info login

8) Alumni login

9) Sistem menampilkan form pengisian data

10) Alumni mengisi data

11) Alumni mengirim form pendaftaran yang telah diisi

12) Sistem menyimpan formulir yang sudah diisi

Spesifikasi Perangkat

\subsubsection{Spesifikasi Perangkat Keras}

Adapun Perangkat Keras yang digunakan untuk membangun Sistem infromasi pengelolaan data alumni Pada UPT SMK Negeri 1 Musi Banyuasin adalah seperangkat laptop yang mempunyai spesifikasi sebagai berikut :

1) Processor Intel Celeron N4000, up to $2.6 \mathrm{GHz}$

2) Memory RAM $4 \mathrm{~GB}$

3) Harddisk 1 terabyte

4) Monitor 14.00"

\subsubsection{Spesifikasi Perangkat Lunak}

Perangkat lunak yang digunakan untuk membuat Sistem Informasi Pengelolaan Data Alumni pada UPT SMK Negeri 1 Musi Banyuasin adalah sebagai berikut:

1) Sistem Operasi (Windows10)

2) Web server (Apache versi 2.4.41)

3) Web browser (Mozila Firefox, Opera, Google Chrome)

4) IDE (Sublime Text 3)

5) Database server (MariaDB Versi 10.4.17)

6) (PhpMyAdmin Versi 5.0.4)

7) (Php Versi 7.4.14)

8) Css (Boostrap)

\subsection{Perancangan Sistem}

1) Usecase Diagram

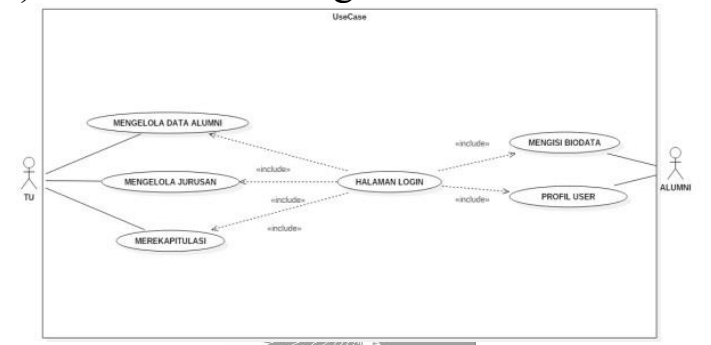

Published by: 
Gambar 3.3 Diagram UseCase mempresentasikan setiap actor dalam system

2) Activity Diagram

a) Admin ( Melewati keamanan sistem / login )

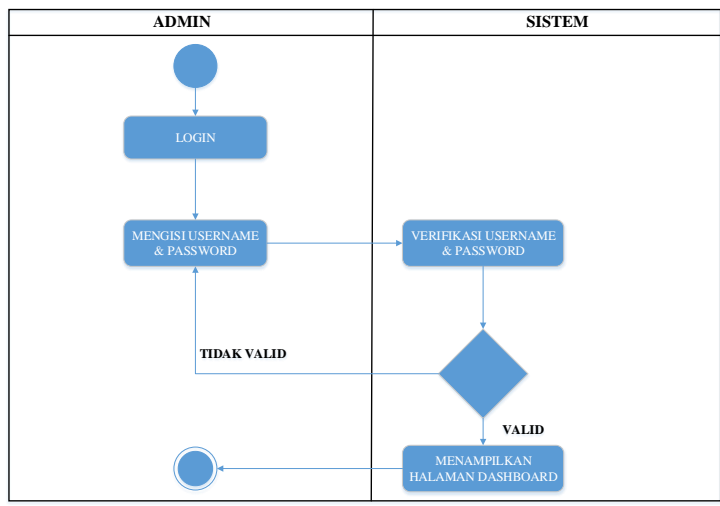

Gambar 3.4 Activity Diagram Login pada admin

Pada gambar 3.4 menjelaskan alur login Admin dimana Admin melakukan input username dan password lalu sistem memverifikasi, dimana jika username dan password benar maka akan menampilkan halaman utama Admin, namun jika username dan password yang di input salah maka akan kembali form input username dan password.

b) Activity Diagram Tambah Data pada Admin

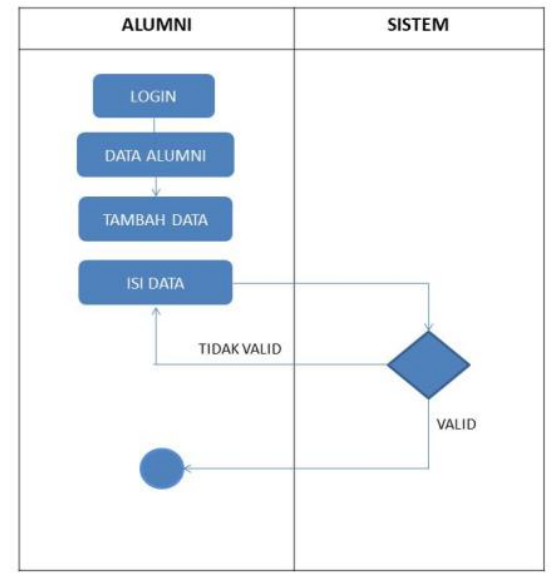

Gambar 3.5 Activity Diagram Tambah data

Pada gambar 3.5 Admin dapat menambah alumni, dengan mengisi NISN, Nama, tanggal lahir, jurusan dan tahun lulus.

c) Activity Diagram Detail pada admin 


\begin{tabular}{l|l|lr} 
J & $\mathbf{N}$ & $\begin{array}{l}\text { JURNAL } \\
\text { NASIONAL } \\
\text { ILMU } \\
\text { KOMPUTER }\end{array}$ & Jurnal Nasional Ilmu Komputer \\
I & $\mathrm{K}$ & e-ISSN: 2746-1343 \\
\hline
\end{tabular}

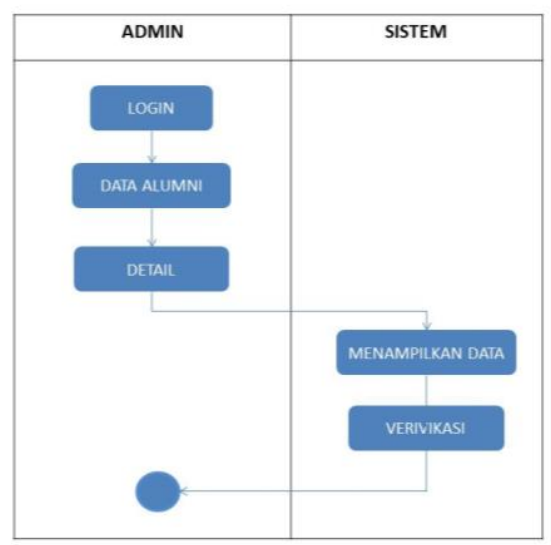

Gambar 3.6 Activity Diagram Detail Pada Admin

Pada gambar 3.6 menjelaskan Admin dapat melihat data alumni yang sudah di isi atau terverifikasi, dan yang belom terverifikasi.

d) Activity Diagram Edit pada Admin

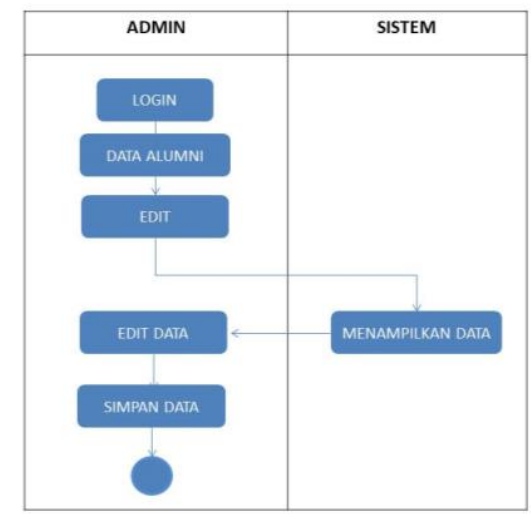

Gambar 3.7 Activity Diagram Edit pada Admin

Pada gambar 3.7 menjelaskan alur edit pada admin dimana Admin hanya dapat mengedit data NISN, Nama, tanggal lahir, jurusan dan tahun lulus.

e) Activity Diagram Jurusan pada Admin 


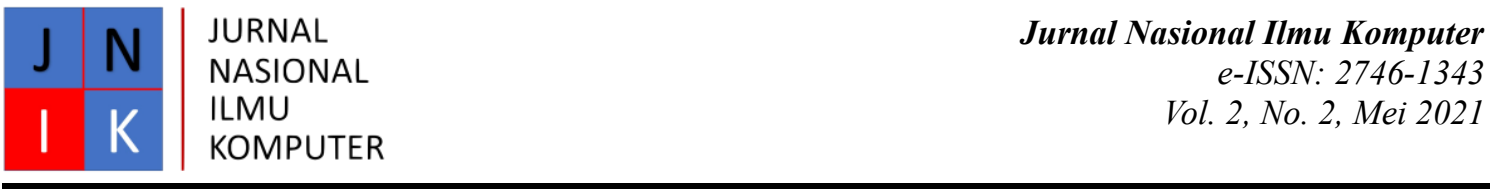

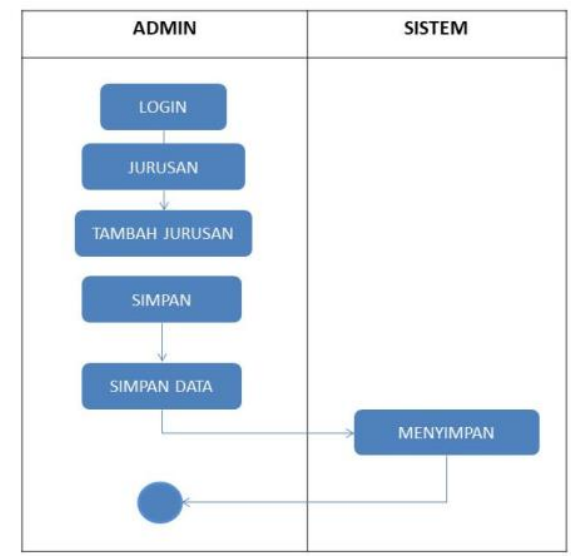

Gambar 3.8 Activity Diagram Jurusan

Pada gambar 3.8 menjelaskan Admin dapat melihat data alumni berdasarkan jurusan, menghapus serta mengeprint.

f) Activity Diagram Login pada Alumni

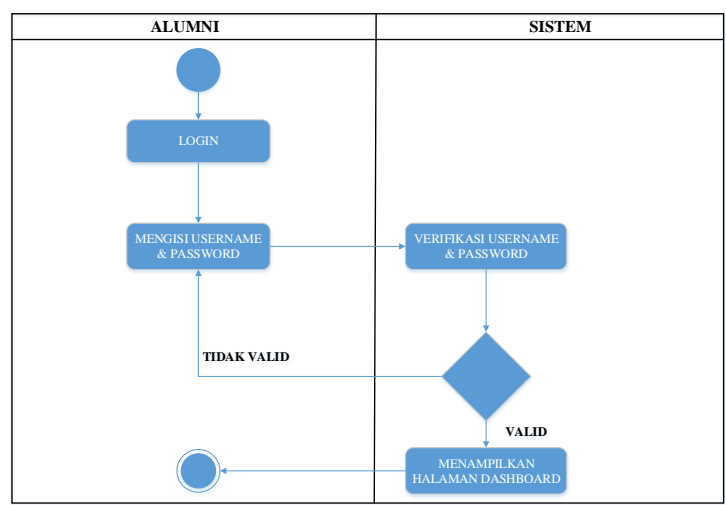

Gambar 3.9 Activity Diagram login pada alumni

Pada gambar 3.9 menjelaskan alur login Alumni dimana Alumni melakukan input username dan password lalu sistem memverifikasi, dimana jika username dan password benar maka akan menampilkan halaman utama Alumni, namun jika username dan password yang di input salah maka akan kembali form input username dan password.

g) Activity Diagram Data Alumni 


\begin{tabular}{l|l|lr} 
J & $\mathbf{N}$ & $\begin{array}{l}\text { JURNAL } \\
\text { NASIONAL } \\
\text { ILMU } \\
\text { KOMPUTER }\end{array}$ & Jurnal Nasional Ilmu Komputer \\
I & $\mathrm{K}$ & e-ISSN: 2746-1343 \\
\hline
\end{tabular}

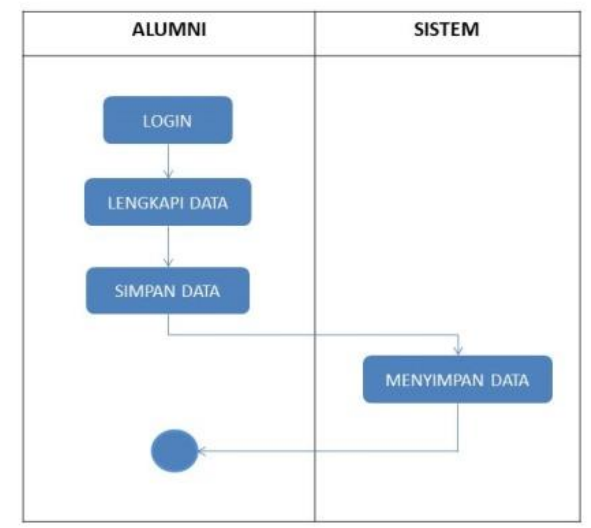

Gambar 3.10 Activity Diagram Data alumni

Pada gambar 3.10 menjelaskan alur data alumni dimana alumni harus melengkapi data yang berupa nisn, nama , alamat, tempat tanggal lahir, nama ayah, nama ibu, pekerjaaan ayah, pekerjaan ibu dll.

3) Sequence Diagram

a) Sequence diagram login

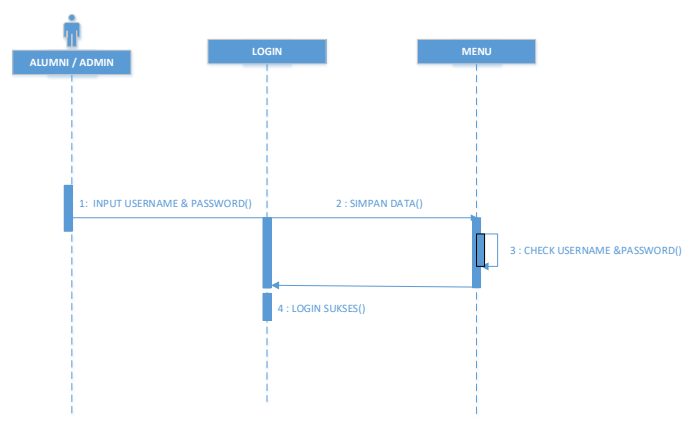

Gambar 3.11 Sequance Diagram login

Pada diagram 3.11 menjelaskan Admin dan Alumni akan melakukan login terlebih dahulu pada Form Login dengan mengisi username dan password, selanjutnya jika benar maka akan masuk ke halaman beranda, jika salah maka akan kembali ke Form Login.

b) Sequence diagram Admin 


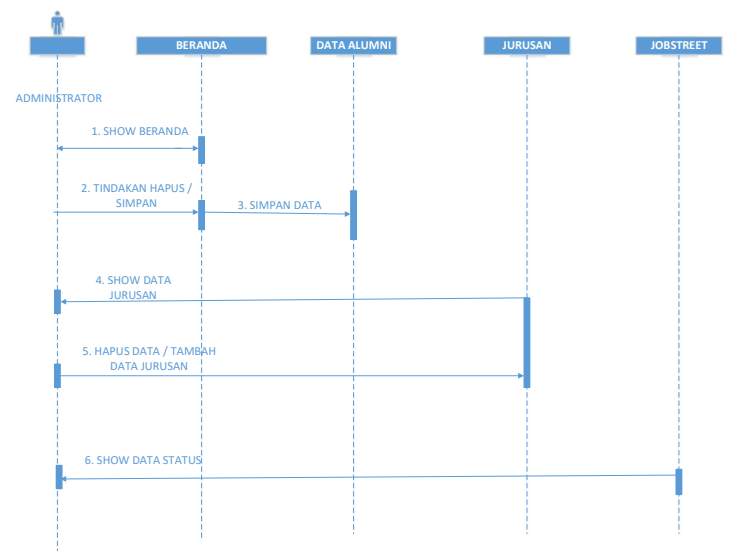

Gambar 3.12 Sequenc Diagram Admin

Pada gambar 3.12 menjelaskan menu pada Admin yang berisi beranda, data alumni , jurusan dan jobstreet.

c) Sequence diagram Alumni

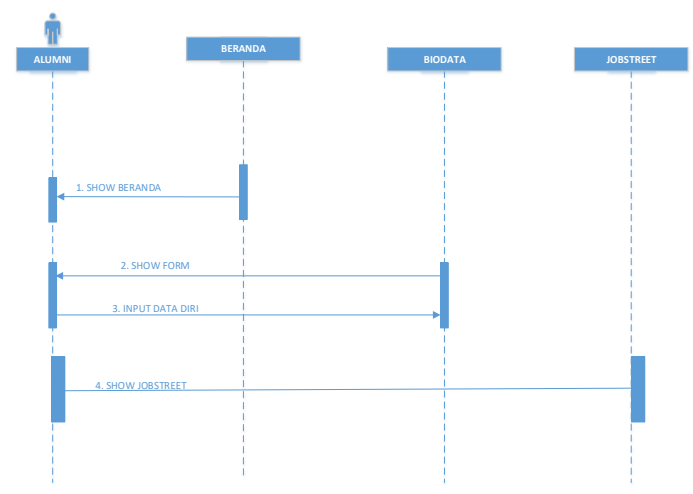

Gambar 3.13 Sequence Diagram Alumni

Pada Gambar 3.13 menjelaskan menu alumni yang berisi menu data alumni dan jobstreet.

\subsection{Perancangan Antarmuka}

Pembuatan bagian ini bertujuan untuk mempermudah membaca menu dari Sistem infromasi Pengelolaan data alumni Pada Upt SMK Negeri 1 Musi Banyuasin. Adapun struktur menu tersebut dapat dilihat pada Gambar 3.3 Menu Admin.

\section{Menu Admin}

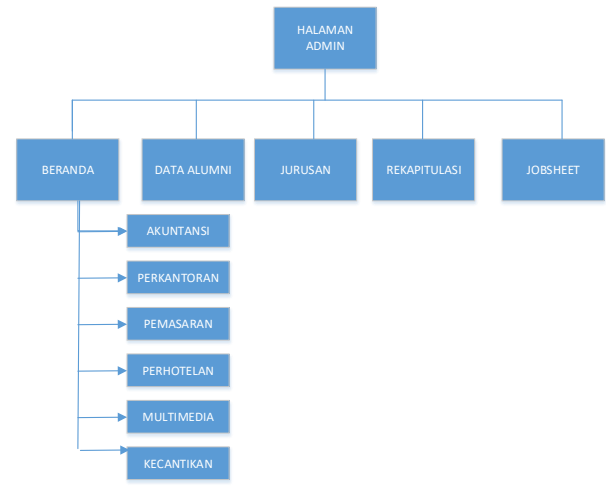


Gambar 3.14 Bagan

Rancangan Menu pada Admin

Pada gambar 3.14 menjelaskan struktur menu pada admin untuk mempermudah membaca menu dari Sistem infromasi Pengelolaan data alumni Pada UPT SMK Negeri 1 Musi Banyuasin .

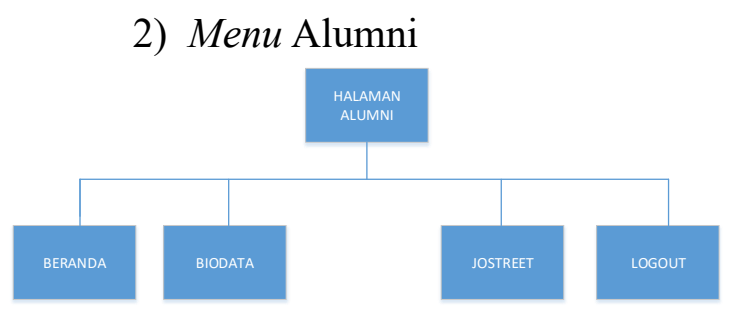

Gambar 3.15 Bagan Rancangan Menu pada alumni

Pada gambar 3.15 menjelaskan struktur menu pada alumni untuk mempermudah membaca menu dari Sistem infromasi Pengelolaan data alumni Pada Upt SMK Negeri 1 Musi Banyuasin .

\subsection{ER-D (Enlity Relationship Diagram)}

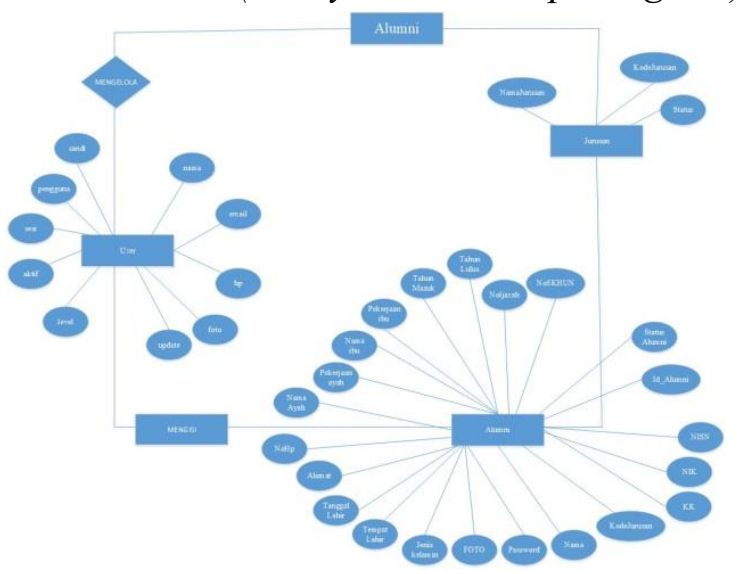

Gambar 3.16 ERD

\subsection{Perancangan Interface}

Perancangan interface merupakan hasil desain tampilan halaman website, sebelum menterjemahkan perangkat lunak yang akan di bangun ke dalam pemrograman, penulis terlebih dahulu merancang tampilan interface website yang akan dibangun. Adapun hasil perancangan interface website yang akan penulis bangun adalah sebagai berikut.

\subsubsection{Perancangan Interface Admin}

1) Interface Login 


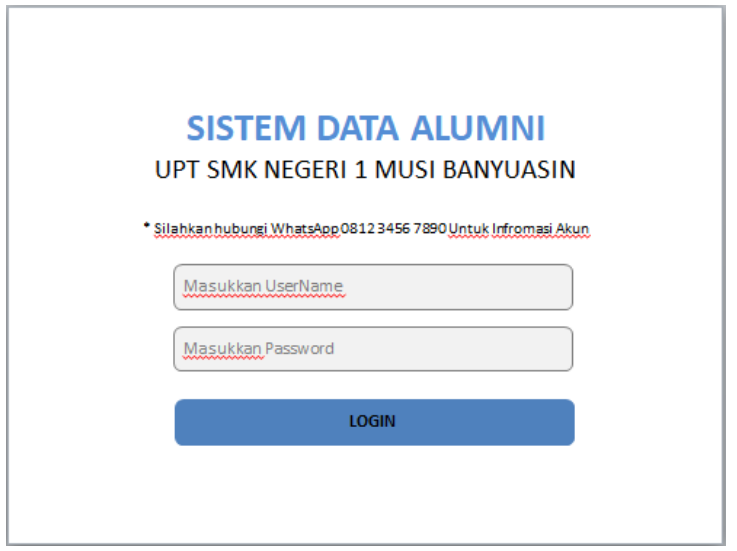

Gambar 3.17 Perancangan Interface Login

2) Interface Halaman Admin

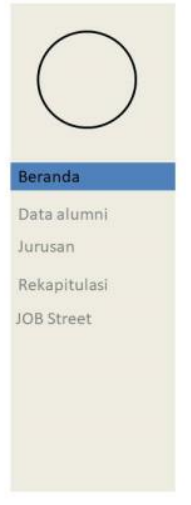

LAMAN ADMINISTRATOR

\section{SELAMAT DATANG}

Gambar 3.18 Perancangan halaman admin Interface Daftar Admin

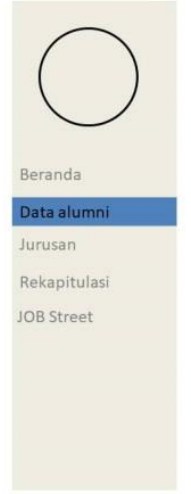

\section{DAFTAR ALUMNI}

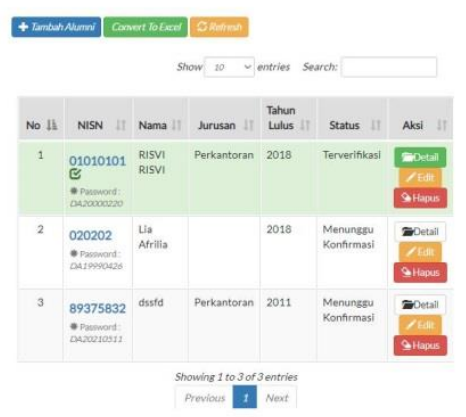

Gambar 3.19 Perancangan Interface daftar alumni

4) Interface Input Daftar Jurusan 


\section{DAFTAR JURUSAN}

Beranda

Data alumni
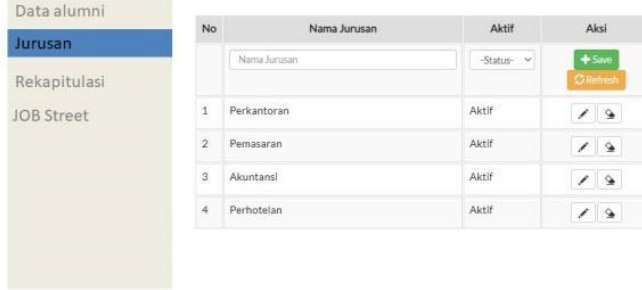

Gambar 3.20 Perancangan Interface Input Daftar Jurusan

5) Interface Rekapitulasi

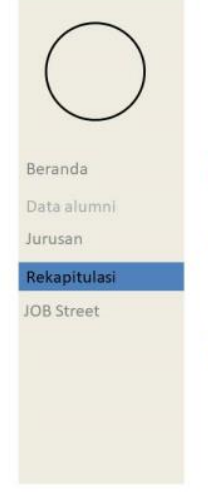

\section{REKAPITULASI}

Gambar 3.21 Perancangan Interface Rekapitulasi

6) Interface JobStreet

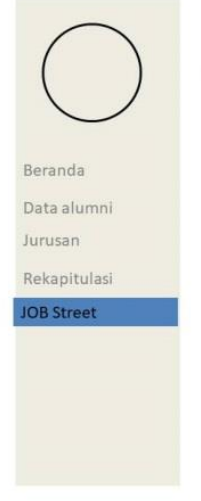

JOB STREET

Gambar 3.22 Perancangan Interface JobStreet

3.6.1 Perancangan Interface Alumni

1) Interface Input Biodata untuk Alumni 


\section{SELAMAT DATANG AFRILIA}

Formulir Alumni Upt Smk Negeri 1 Musi Banyuasi

Information!

Beranda

Silahkan lengkapi formulir biodata berikut dengan data yang valid

JOB Street

Logout

NO IMAGE

AVAILABLE

nepicpres

Choose file No tilechosen

Gambar 3.23 Perancangan Interface Input Biodata alumni
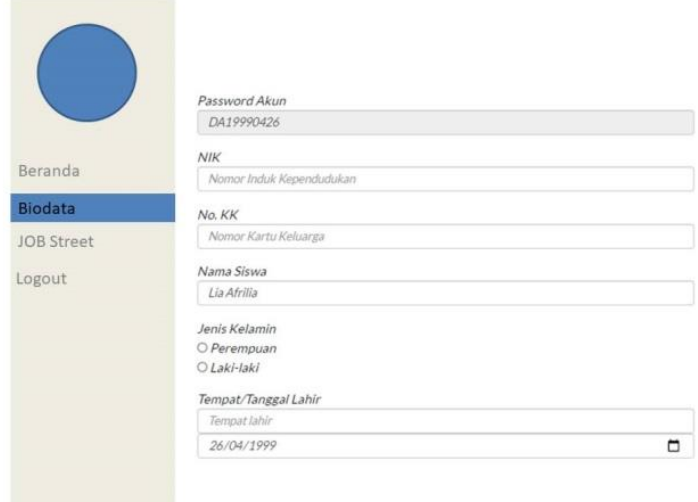

Gambar 3.24 Perancangan Interface Input Biodata alumni1
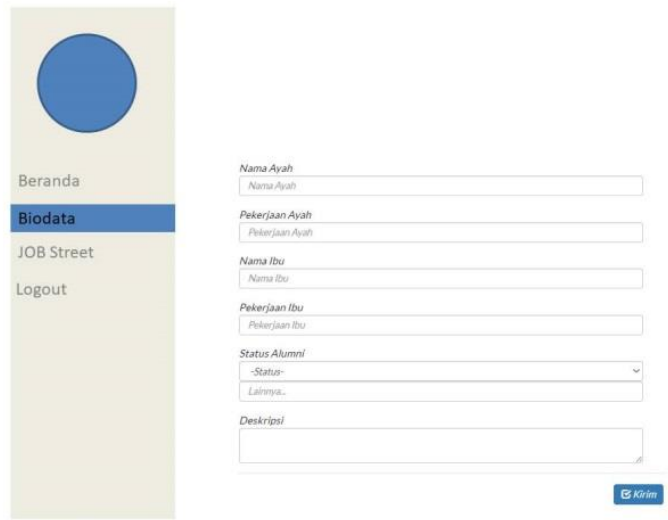

Gambar 3.26 Perancangan Interface Input Biodata alumni3

\section{Hasil dan Pembahasan}

\subsection{Hasil Implementasi Perancangan Sistem}

Laporan Tugas Akhir yang dibuat adalah Sistem informasi pengelolaan data alumni pada UPT SMK Negeri 1 Musi Banyuasin. Sistem ini terdiri dari 2 (dua) halaman utama yaitu admin, dan Alumni. Pada halaman admin terdapat beberapa menu yang bisa di akses yaitu profil, Data alumni, Dan sebelum masuk ke halaman admin akan tampil form login untuk admin. Kemudian admin dapat melakukan aksesnya yaitu input, edit, dan delete data pada menu admin. dan pada halaman alumni terdapat beberapa menu yang bisa di akses yaitu 
menu biodata dan jobstreet.

\subsection{Pengujian Sistem}

\subsubsection{Halaman Admin}

Ada beberapa form pada halaman antarmuka admin yaitu form input data dan edit data. Adapun tombol yang ada pada antarmuka halaman admin yaitu login, input, edit, delete dan simpan.

1) Tampilan Login

Pada halaman admin yang muncul pertama ialah form login. Administrator harus mengisi username dan password untuk dapat mengakses halaman admin. Klik tombol login agar sistem dapat melakukan pengecekan dan otorisasi username dan password administrator.
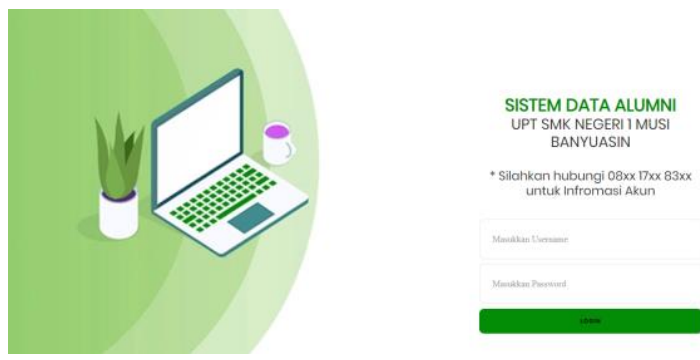

Gambar 4.1 Tampilan login

Jika terdapat kesalahan dalam mengisi username atau password terjadi kesalahan, akan muncul tampilan pop up berikut.

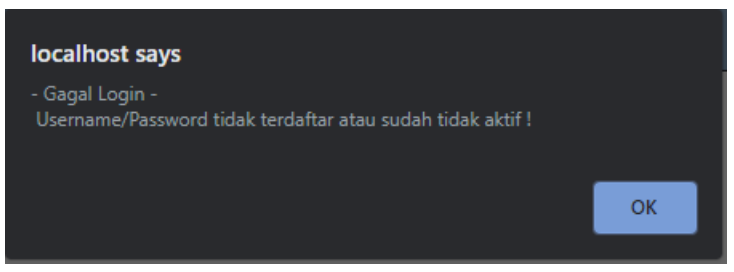

Gambar 4.2 Tampilan Jika Login Gagal

2) Tampilan Halaman Beranda

Antarmuka halaman akan tampil seperti pada gambar berikut jika administrator berhasil login. Pada halaman beranda menampilkan halaman beranda.

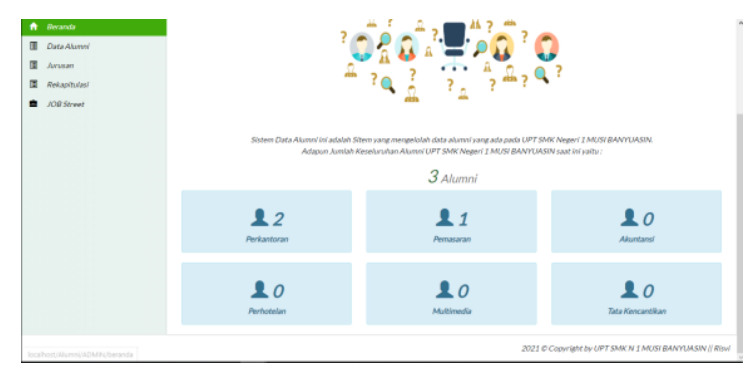

Gambar 4.3 Halaman Beranda

3) Tampilan Halaman Data Alumni

Halaman menu Data alumni terdapat form Data alumni dan beberapa button tambah alumni, convert to exel, PDF, refresh, pencarian. 


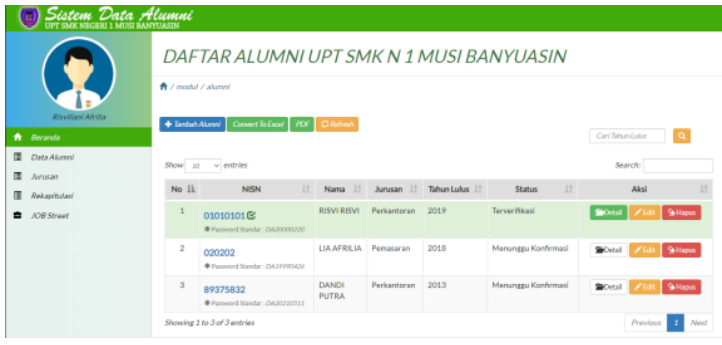

Gambar 4.4 Tampilan Data Alumni

a) Tampilan Button tambah alumno

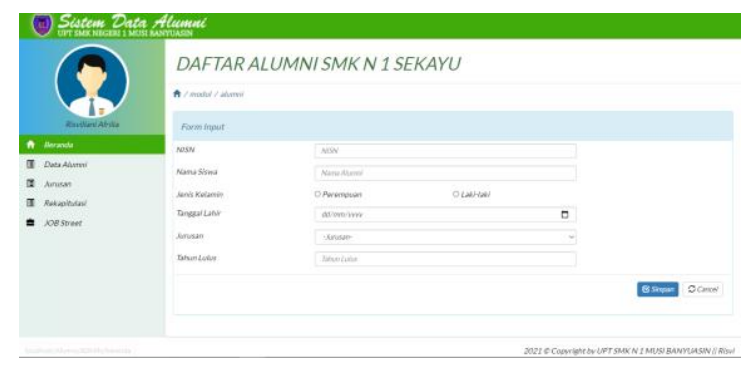

Gambar 4.5 Tampilan Tambah Alumni

b) Tampilan setelah di simpan format PDF

Jika tombol PDF diklik maka data alumni akan tersimpan.

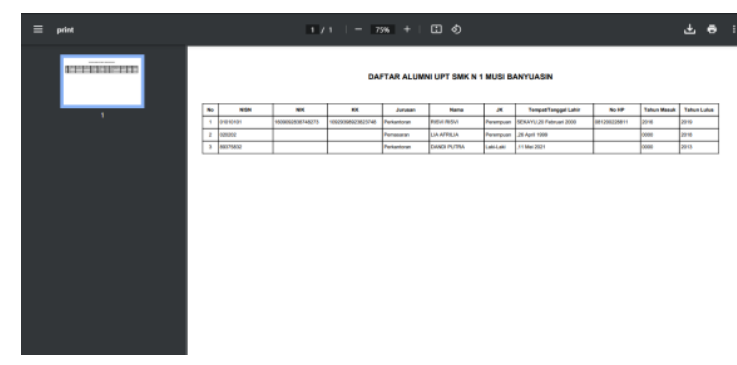

c) Tampilan pencarian berdasarkan tahun

Dibawah ini menampilkan pencarian Data alumni tahun 2019

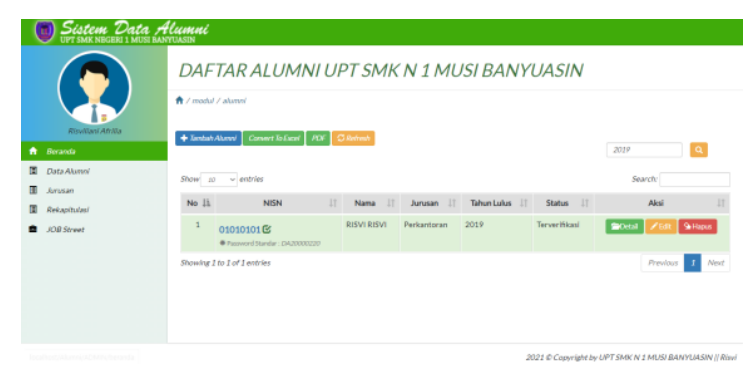

Gambar 4.7 Tampilan Pencarian berdasarkan tahun

4) Halaman Menu Jurusan

Tampilan antarmuka halaman menu Jurusan terdapat beberapa jurusan. 


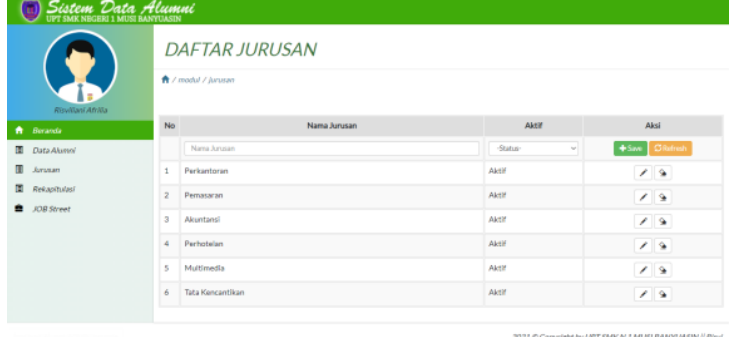

Gambar 4.8 Tampilan menu jurusan

5) Halaman Rekapitulasi

Tampilan antarmuka halaman rekapitulasi terdapat data alumni pencarian berdasarkan tahun, jumlah perempuan, jumlah laki-laki dan jumlah angkatan perjurusan. Menggunakan diagram

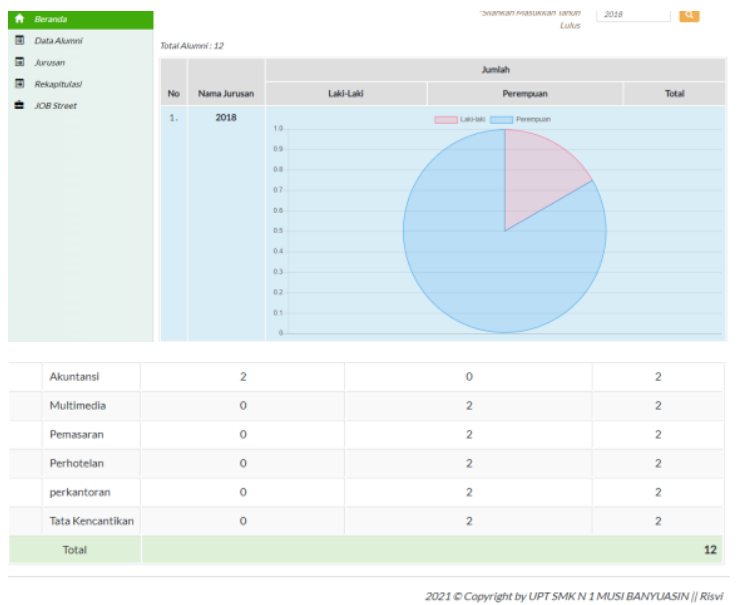

Gambar 4.9 Tampilan Rekapitulasi data alumni

\subsubsection{Halaman Alumni}

1) Halaman Beranda Pada Alumni password.

Tampilan antarmuka halaman beranda pada alumni terdapat button ganti

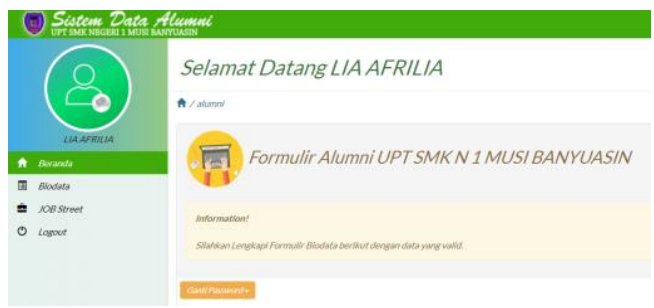

Gambar 4.10 Tampilan Beranda pada alumni

a) Button ganti password

Dibawah menampilkan isi button ganti password 
Ganti Password -

Masukkan Password

Ulangi Password

\section{¿ Ganti}

Gambar 4.11 Tampilan Ganti Password

2) Halaman Biodata pada Alumni

Tampilan antarmuka halaman Biodata yang berisi nama, tempat lahir, tanggal lahir, nama ayah, nama ibu, NISN dll.
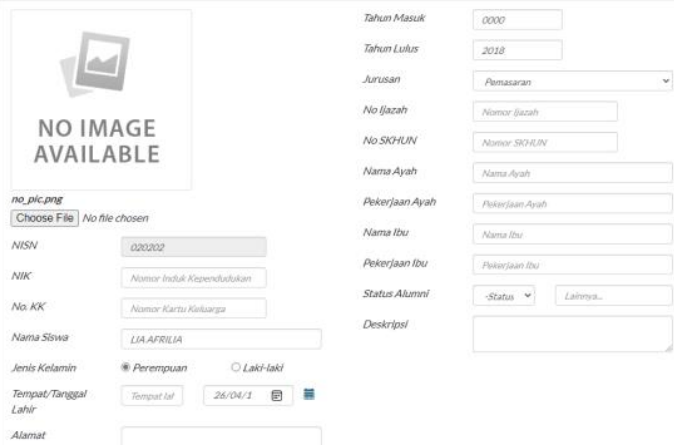

Gambar 4.11 Tampilan format pengisian Biodata

\subsection{Pengujian}

Sistem informasi pengelolaan data alumni pada UPT SMK Negeri 1 Musi Banyuasin yang telah dirancang perlu diuji melalui berbagai proses pengujian. Pada sistem ini, proses pengujian menggunakan black box testing.

Pada pengujian aplikasi ini diterapkan nilai yang harus di isi oleh penguji. Nilai yang diisi berdasarkan kriteria yang ada. Berikut ini adalah nilai dan kriteria yang menjadi acuan dalam pengujian aplikasi.

Berikut ini adalah rekap hasil pengujian terhadap Sistem informasi pengelolaan data alumni pada UPT SMK Negeri 1 Musi Banyuasin.

\subsection{Pembahasan}

Sistem Informasi pengelolaan data alumni pada UPT SMK Negeri 1 Musi Banyuasin ini dibuat menggunakan pemrograman PHP dan database MySQL yang digunakan untuk menyimpan data dan menginput, edit serta menghapus data pada halaman admin. Dengan adanya Sistem ini pihak sekolah akan lebih mudah untuk mengelola data alumni, dan mempermudah alumni dalam mengisi data alumni tanpa harus datang ke sekolah.

\section{Kesimpulan}

Sistem informasi pengelolaan data alumni pada UPT SMK Negeri 1 Musi Banyuasin, ini 
merupakan perancangan dari sistem yang sedang berjalan. Berbagai permasalahan yang muncul telah diupayakan untuk dapat ditangani dengan sistem yang baru ini, adapun kesimpulan yang dapat diambil antara lain:

1. Dengan dibuatnya Sistem informasi pengelolaan data alumni ini dapat mempermudah Staff UPT SMK Negeri 1 Musi Banyuasin dalam mengelola data alumni.

2. Pengolahan data alumni yang akan ditampilkan dalam Sistem adalah Data Alumni pada UPT SMK N 1 Musi Banyuasin berdasarkan tahun angkatan

3. Pengolahan data hanya bisa dilakukan oleh administrator. Hak akses alumni meliputi mengisi data alumni. Proses pencarian data alumni berdasarkan kriteria-kriteria tertentu, seperti berdasarkan Nama, jurusan, dan tahun lulus.

\section{Referensi}

18 Pengertian Website Menurut Para Ahli, Syahid, Bilal 2019, di akses tanggal 12 februari 2021, < https://gurupendidikan.co.id/pengertian-website-menurut-para-ahli, >

Andini Mia, Khairul Anwar Hafizd, ' Perencanaan Dan Pembuatan Aplikasi Alumni Siswa (Studi Kasus Smk-Spp Negeri Pelaihari)', Jurnal Sains dan Informatika, Vol. 1,No. 2. 2015

Antoni, D., \& Akbar, M. (2019). E-supply chain management value concept for the palm oil industry. Jurnal Sistem Informasi, 15(2), 15-29.

Antoni, D., Fikari, D., \& Akbar, M. (2018). The readiness of palm oil industry in enterprise resource planning. Telkomnika, 16(6), 2692-2702.

Antoni, D., Jie, F., \& Abareshi, A. (2020). Critical factors in information technology capability for enhancing firm's environmental performance: case of Indonesian ICT sector. International Journal of Agile Systems and Management, 13(2), 159-181.

Fauzi, F., Dencik, A. B., \& Asiati, D. I. (2019). Metodologi Penelitian untuk manajemen dan akuntansi. Jakarta: Salemba Empat.

Hadi. 2013. Pengembangan Computerized Adaptive Test, Berbasis Web.

Kritanto, Andri. 2011. Kupas Tuntas Php dan MySQL, Klaten:Cable Book

Metode Prototype, Prayudita raheza, di akses tanggal 11 juni 2021, $<$ https://www.materikuliahif-unpas.com/2018/07/metode-prototype.html $>$

Pengertian Flowchart dan jenis-jenisnya, Informatikalogi, di akses tanggal 12 juni 2021, $<$ https://informatikalogi.com/pengertian-flowchart-dan-jenis-jenisnya/, $>$

Pengertian, Fungsi, Model dan Contoh ERD, Imaludin nur islam, di akses tanggal 11 juni 2021, < https://tisucoding.com/contoh-erd/, >

Peranginangin, Kasiman, 2015, Aplikasi WEB dengan php \& MySQL Yogyakarta:Andi.

R. A. Sukamto dan M. Shalahuddin, Rekayasa Perangkat Lunak, Bandung: Informatika, 2015.

Shara Asima Putri Sibarani, Junika Napitupulu, Jamaluddin , 2017, ‘ Aplikasi Pengolahan Data Alumni Diploma Tiga Manejemen Informatika Universitas Methodist Indonesia Medan ', Jurnal Manajemen Informatika \& Komputerisasi Akuntansi, vol. 1, No .1. 
Shelly, Gary B.dkk.2010. Menjelajah Dunia Komputer. Jakarta: Salemba Infotek.

Simarmata, J 2010.Rekayasa Perangkat Lunak, Andi, Yogyakarta .

Sugiarti, Y 2013, Analisis \& Perancangan Uml (Unified Modeling Language) Graha Ilmu, Yogyakarta.

Use Case diagram, Shalahuddin Muhammad di akses tanggal 12 juni 2021, <http://www.damankom.com/2020/12/use-case-diagram.html>

Watung, Ivan Arifard, Alicia A. E. Sinsuw, ST.,MT, Sary D. E. Paturusi, ST.,M.Eng, Xaverius B. N. Najoan, ST.,MT, 2014, 'Perancangan Sistem Informasi Data Alumni Fakultas Teknik Unsrat Berbasis Web', e-journal Teknik Elektro dan Komputer.

Widuri.raharja.info . Penjelasan Company profile, Tanggerang: Teknik Informatika, 2014.

\section{Copyrights}

Copyright for this article is retained by the author(s), with first publication rights granted to the journal.

This is an open-access article distributed under the terms and conditions of the Creative Commons Attribution license (http://creativecommons.org/licenses/by/4.0/) 